\title{
Self-Leadership and Gamification as Madani Society's Human Resource Educational Elements
}

\author{
Satria Asyraf bin Yahya* and Hailan Salamun \\ Pusat Pendidikan Asas dan Lanjutan, Universiti Malaysia Terengganu, Terengganu \\ *Corresponding author. Email: p3706@pps.umt.edu.my
}

\begin{abstract}
Volatile and unpredictable technological advancement in the 21 st century has caused frequent paradigm shift. Aside from ensuring that the nation is ahead of the technological and economical race, human resource in this era must also ensure good leadership to balance thought, spiritual and material to achieve the state of prosperous nation. This paper discusses Self-leadership and Gamification as potential important element in educating human resources of a Madani society. Self-leadership is a set of strategies that are divided into three categories: focused behaviour, constructive cognitive pattern and natural rewards aimed to influence oneself resulting in the increase in individual's performance. Self-leadership differs with conventional organizational leadership which focuses on the ability of a specific character in an organization (leader) to influence the behaviour of his or her subordinates. Self-leadership on the other hand, focuses on the leadership phenomenon at an individual level. Gamification is a body of knowledge that discusses the application of game design framework into productive activities or things such as education or product creation. This body of knowledge stresses on the alignment of product or system produced with human's extrinsic and intrinsic tendencies. Products or systems produced using formal gamification framework has a high potential to become sustainable in its consumption. The combination between Self-leadership and Gamification is expected to be a relevant tool for Madani society's human resource. Interestingly, these ideas share some common ground with Islamic philosophies such as Rabbani leadership, akhlak exercises by Imam al-Ghazali and education methodologies by Ibnu Khaldun.
\end{abstract}

Keywords: Prosperous Nation, Madani society, Self-leadership, Gamification

\section{INTRODUCTION}

In the advent of various tools and software that automate most of industrial tasks, human capital is gradually being freed from algorithmic tasks [1]. This results into the paradigm into shift in human capital market which favours human capital that is adept with heuristic tasks. Heuristic tasks require more leadership from individuals as the tasks are more complex as compared to algorithmic tasks that can be regulated using manual transcripts. In working environment, aside from technical prowess obtained from studying years, human capital must also possess strong soft skills to efficiently communicate with stakeholders to achieve the organization's goals [2]. In short, human capital tasks nowadays are no longer specific steps specified by a leader in an organization. Instead, one must be able to specify one's own mission, guided by shared visions in an organization and able to motivate oneself to complete the missions.

While some of us are lucky to be intrinsically rewarded by the work we do, most of us are not intrinsically satisfied by our tasks at hand. Although lot of thoughts are put into ensuring material gains, failure to also include spiritual aspect in work will cause imbalance that resulted to unhappy individuals and societies, leading to maybe rich but unprosperous nation. This is a waste of human capital as intrinsic satisfaction in work has been related to high work quality and productivity [3]. Self-leadership is a process whereby an individual influence oneself to set self-direction and achieve self-motivation to complete tasks at hand. Established self-leadership contains a set of behaviour and normative strategies that is categorized into 3 categories, focused behaviour strategy, constructive 
cognitive pattern, and natural rewards [4]. These strategies revolve around establishing an understanding about one's spiritual inclinations, reshaping them if necessary and to leverage on correct spiritual beliefs to achieve discipline and motivation to complete self-directed missions.

Self-leadership can potentially act as a tool for human capital in Madani society to balance their thought, spiritual and material. Gamification on the other hand, focuses on creating tasks, products or services that can exist in harmony with humanity's intrinsic needs. This body of knowledge involves the application of game elements into non-game products or services to increase user's motivation, engagement, and retention [5]. Game elements discuss what drives motivation, how motivation can evolve and the phenomena when an activity is done with intrinsic motivation. Creating a task with these elements in mind can potentially result into quick uptake to kick-off tasks, motivate engagement with the tasks and ultimately helps human capital to achieve high productivity while being intrinsically satisfied.

Since most of Malaysians are Muslims, it is only appropriate to also discuss this matter from Islamic philosophical view [6]. Interestingly, although Islamic philosophy such as al-Ghazali views that are heavily Sufiinfluenced, is always perceived to only put weightage on spiritual aspects of life, literature review on his works reveals that al-Ghazali also emphasize balance of thought, spiritual and materialistic inclinations to achieve ultimate happiness in life [7]. Similarities has been found in alGhazali and Ibnu Khaldun's views with Self-leadership and Gamification. This paper discusses the potential of Self-leadership strategies and formal Gamification frameworks through Islamic philosophical lenses of alGhazali and Ibnu Khaldun as potential Madani society's human capital educational elements.

\section{LITERATURE REVIEW}

\subsection{Definition of Leadership}

In Islam, leadership is a form of servitude to Allah. It is a form of trust placed onto humankind. In organizational setting, leadership is the responsibility of each person in the organization to carry out tasks given to them. The leader is responsible to provide guidance for the subjects in spiritual, intellect and materialistic matters. While it is a responsibility of a subordinate to be loyal towards a leader's command, subordinates also has a responsibility to know the vision of the organization and provide feedback through the right procedures if the leader make a mistake [8]. In term of accountability, each person is held accountable to one's action or behaviour. This is as per hadith,

"Each one of you is a leader and each one of you will be held accountable for your responsibilities" (Hadith Muslim)

This hadith also shows that in Islamic philosophical thinking, normal humankind has free will or voluntary control over one's behaviour. Thus, leadership in Islam focuses on guidelines of right behaviours and the emphasize on the need to practice them as a way of life. In Western philosophy, leadership is studied as a form of phenomena. In organizational setting, leadership is the influence exerted by a leader to the subordinates. A leader exerts his or her influence by establishing the organizational vision, specifying missions and influence the synergy between the members of the organization to move the organization towards a goal [9]. Western philosophy did not elaborate on a subordinate's leadership role in an organization but discusses another form of leadership at individual level, self-leadership. Selfleadership is the influence exerted by an individual upon oneself by specifying self-direction and maintaining selfmotivation to complete tasks [4]. From observation in various cases, researchers of self-leadership have specified various normative and cognitive strategies to provide selfdirection and maintain self-motivation. The strategies revolve around introspective exercises to understand oneself better and leverage on one's natural inclinations.

Comparing leadership definitions from Islamic thinking and Western philosophical thinking, both definitions are similar in that leadership is a phenomenon that happen in two settings, organizational and individual level. While Western philosophy mainly focuses on deriving descriptive and prescriptive theories from their study on leadership, Islamic philosophy leadership as a form of worship that must be done correctly. As such, Western studies on leadership are more result-oriented and agrees with any leadership strategies or methodologies that allows an organization or an individual to achieve specified goals. Islamic studies on leadership on the other hand, is a derivative from the religion itself, thus aside from studying functional leadership strategies and methodologies, Islamic scholars also focus on deriving the correct or allowed leadership strategies based on Islamic teaching.

"A child is like a white sheet of cloth, parents are the ones who will put patterns on it and determine that the child will be a Christian, a Jew or a Zoroastrian" (Hadith Muslim and Bukhari)

In Islam, a child is Islam by nature. However, it is important the parents to control external influences that is perceived by a child. This is because, a child's psyche is not yet fully developed in the early years of its life [10]. This view of human behaviour is a function of external influences is also shared by Western philosophy in behaviourist learning theory. This theory discusses the function of conditioning in maintaining or changing a behaviour. Conditioning is the relationship between stimulus and response [11]. Classical conditioning allows for a neutral stimulus to be associated to a natural stimulus and its respective natural response. As for example, when an individual is subjected to a routine where bell is rang (neutral stimulus) at the same time the individual smells food (natural stimulus) during meal time (natural response), in a considerable amount of time, the individual theoretically will associate the sound of bell to meal time. Meanwhile, operant conditioning involves reinforcement to reinforce the sense of consequence of a response to a 
stimulus [12]. As for example, rewarding a child with the child's favourite meal after the child finishes homework reinforces that finishing homework is a response that will yield good consequences.

"Indeed, in the creation of heavens and earth, and the alternation of day and night, there are signs for people of reason (Ulul Albab)" (Ali Imran, verse 190).

Based on this Quran verse, human could perceive the world and has innate ability to synthesize information from the nature by oneself without the interference of external influence. Al-Ghazali proposes that one of the elements of human psyche is aql (thought). Aql is the element of human psyche that enables an individual to understand, memorize and analyse events that the individual has directly or indirectly experienced and perceived [13]. Wood \& Bandura (1989) [14] agrees in this matter by suggesting that human behaviour is a result of interconnected relationship between external stimulus, response, and cognitive factor. Cognition enables one to set standards from its learning and observe one's own response. Discrepancy between one's own performance and one's set standard will be followed by discrepancy reduction process. This perception of discrepancy and discrepancy reduction process is called self-efficacy that has a strong relationship with work performance of an individual.

In akhlak training concept, al-Ghazali suggests that there are behaviours that are naturally favoured by an individual. If the behaviour is already a good behaviour than practicing the behaviour is called riadah but if the behaviour is wrong and need to be stopped, then the process is a very hard task that requires strong determination (mujahadah) but is not impossible and need to be the will of the individual (al-Ghazali, 2010). Ryan \& Deci in their discussion about the concept of motivation also propose similar argument. Motivation is a construct that concerns with the energy, direction, determination and all aspects of activation and intention. Self-determination theory divides motivation into two; intrinsic and extrinsic motivation. In cognitive evaluation theory, segregation between these two types of motivation is determined by 3 main elements, competency, autonomy, and relatedness. The possibility of evolving one's motivation to practice a behaviour is discussed in organismic integration theory which puts apathy (no motivation at all), extrinsic motivation and intrinsic motivation in a spectrum. The taxonomy of this spectrum is determined by the drive factors and the hindering factors of the motivational spectrums [3].

Akhlak training according to al-Ghazali is started with muhasabah, a self-reflection exercise to assess one's current performance and set standards by referring to experts. This is followed by muraqabah, the exercise of assessing one's planned performance according to the standards set from referring to the experts [15]. If behaviour change is needed and it hard to do, then conditioning one's environment such as being the presence of experts at most of the time and practicing zikr to reinforce the reward or the consequence of the behaviour change are suggested. By doing so, al-Ghazali suggested that it is possible to evolve mujahadah to riadah or to evolve extrinsic motivation to intrinsic motivation through repeated practices of the behaviour [16]. Western philosophy also has their fair share of normative theories to assist behaviour change such as self-management theory and self-regulation theory [4]. These theories share similarities with akhlak training by al-Ghazali in that they start with discrepancy detection by self-observation, selfevaluation, and self-response. These steps are then followed by strategies to reinforce behaviour change such as self-cues, self-rewarding or punishment, and practices.

All in all, it is interesting to notice that Islamic philosophy and Western philosophy share quite a lot of common ground in term of self-leadership theoretical framework. Both involves initially, the establishment of human psyche to ascertain human's nature. Next, both discusses how to leverage from the knowledge of these human natures and suggests normative strategies to help an individual achieve behaviour change. The main difference between Islamic philosophy and Western philosophy is the discussion about spirituality. While Western philosophy is more focused on constructs with more empirical in nature, Islamic philosophy revolves around using the behaviour change to enable an individual to take a step closer to Allah. In that, Western philosophy view self-direction as the result of one's natural tendencies hence no right or correct selfdirection while Islamic philosophy views self-direction to be a choice of good or bad choice depending on its association with servitude towards Allah and Allah's help and will are needed in the path towards behaviour change.

\section{$2.2 \quad$ Self-leadership strategies}

Self-leadership is a combination of normative and cognitive strategies to help one set self-direction and maintain self-motivation to complete tasks. Scholars have been categorizing these strategies into 3 categories; focused behaviour strategy, constructive cognitive pattern, and natural reward [4].

Focused behaviour strategies are strategies to increase selfdiscipline to drive an individual to complete necessary task that is not enjoyed by the individual [17]. Strategies in this category include, self-observation, self-evaluation, selfgoal setting, self-reward, or punishment, self-cueing and practice. Al-Ghazali suggested similar steps to these strategies in akhlak training. Akhlak training starts with muhasabah (self-observation and self-evaluation), an exercise where an individual's current performance is assessed, and standards are set by referring to experts and ultimately by oneself [15]. Should there be any discrepancies between current or performance to the path of servitude towards Allah, taubat (repentance) is necessary. There are 3 steps in repentance, stop doing the wrong actions, regret doing the wrong actions and determined not to repeat the wrong actions [18]. In Islamic philosophy, self-goal setting must always be rooted to Allah.

"Verily, every action is only dependent on intentions, and everyone will get what he intended" 
Niat or intention contains three things, what action to be done, how it is completed and for whom it is done for [19]. At first, when practicing new, unnatural behaviour with respect to an individual, it is hard and as such, practice which is the repetition of the behaviour is called mujahadah. Self-reward or punishment can be given to reinforce one's intended behaviour. Imam al-Ghazali's form of self-reward includes the reminding of Allah's blessings while self-punishment includes self-loathing for not being grateful of Allah's blessings [15]. It is important to remember that excessive self-loathing of selfpunishment may bring more harm as proven in recent research [20].

Constructive cognitive pattern strategies are strategies that focus on modification or building one's thinking patterns which in turn will affect how one process information and make decisions. Strategies in this category include identifying and displacing dysfunctional beliefs and assumptions, mental imagery, and positive self-talk [21]. In Islam, the correct beliefs are to be learned. Imam alGhazali proposed that each Muslim is equipped with 3 core knowledges (fardhu 'ain) which are Islamic theology (tauhid), method of worship (fiqh) and method of spiritual worship (sir). Islamic theology discusses characteristics of Allah so that an individual can differentiate wrong and right faith. Worship methodologies are learned so that Muslim individuals practice the correct method of worship as decreed in Quran and Hadith. Spiritual worship education aims to educate Muslim individuals to differentiate which impulses to be supressed and which impulses to be allowed to become behaviour [22]. Next, Imam al-Ghazali suggests muraqabah, a practice to vividly imagine actions to be taken so that the consequences can be analysed mentally. This helps to assess actions before it is realized and to determine the best course of action possible. Muraqabah (mental imagery) can also work as mental form of practice that is said to have same effect as physical practice in perfecting real performance [15]. In Western philosophy, positive self-talk includes monologues that help one to feel more confident about one's ability to carry out a task [21]. In Islam however, $d u^{\prime} a$ (praying) and zikr are suggested as Muslims believe in Quran and one of the verses says;

"And your Lord says "Make $d u$ ' $a$ to Me and I will respond to you. Indeed, those who disdain My worship will enter Hell in humiliated way" (Al-Ghafir, verse 60)

This verse suggests that Muslims should believe that Allah will always answer their prayers provided if one is mindful of one's worship of Allah.

Natural reward strategies leverage on creating environment or choosing tasks that can increase motivation or believed to be intrinsically rewarding. The first strategy involves shaping one's own perception towards tasks at hand to make it seem intrinsically rewarding. This includes understanding the task at hand and find any aspects of the task that is relatable, empower autonomy by voluntarily choosing tasks to carry out and choosing tasks within one's competency. The second strategy involves modifying the work environment with intrinsically motivating elements such as working while listening to music or working at a favourite café [4]. This strategy has also been suggested by al-Ghazali in that he suggests being in the presence of experts or those who practices one's intended behaviour to help one adopt the intended behaviour [15].

In a nutshell, according to Imam al-Ghazali, selfleadership strategies suggested to Muslims include muhasabah, muraqabah, taubat, niat, mujahadah, du'a, $z i k r$, and riadah. These strategies aligned with selfleadership strategies from the Western philosophy which themed around understanding what motivates human to do things and leverage on them to maintain the motivation needed to carry out the tasks. The only main difference is that in Islam, obedience to Allah creates an axiom that separates a correct way of doing things and the wrong way of doing things as opposed to Western philosophy that is not concerned about correct or the wrong way or goal, it merely discusses how a goal can be achieved.

\subsection{Gamification theoretical framework}

Gamification is the application of game design elements into the design of non-game product or services to increase user's motivation, engagement, and retention [5] Gamification, however, differs from game-based learning in that it only applies game design elements into the design of a product or a service and not making a game. Gamification is not only effective towards younger generation, but also to adult and old generation. Research has shown that $47 \%$ respondents at United States are active video game players. Gamification scholars argue that gamification is not a simple matter of including PBL (points, badge, and leader boards) into a product or service [23]. Instead, gamification includes wider discussions including motivational theories and phenomena to explain formal gamification framework

One of the gamification theoretical framework is selfdetermination theory by Ryan \& Deci [24]. Cognitive evaluation theory, a sub-theory of self-determination theory suggests that motivation is a combination of autonomy, competency, and relatedness [24]. Meanwhile, Daniel Pink in his motivational drive theory suggests that motivation is driven by autonomy, mastery and purpose [25]. These presence of these motivational drives in doing a task produces intrinsic motivation as one carries out the task.

"There is no compulsion in matter of faith. The right course has become clear from the wrong" (al-Baqarah, verse 256)

This verse shows that Islam values autonomy especially in a matter of faith since obedience means nothing when someone feels forced to do something.

"The best among you are those who learn Quran and teach it" (Hadith Bukhari)

This hadith shows that Islam values competency of knowledge and the sign of the highest level of competency is the ability to teach the knowledge to others. The idea of competency levels in education is also suggested by Ibnu Khaldun in his book, al-Mukaddimah. He suggested that an ideal education has 3 levels, introduction, 
comprehension, and mastery. At mastery level, an individual can define every problem of one's study and produce vocational and practical products or services from the body of knowledge. Ibnu Khaldun also suggests an abstract called assabiyyah which means the quality of one's understandings or to relate with one's social norms. From observing various societies, he hypothesized assabiyyah to be an important construct in determining the strength of the society and the leadership of the society [26].

"And seek help in patience and in prayer. And indeed, it is difficult except for the humbly submissive (to Allah)" (alBaqarah, verse 45)

From this verse, Islamic scholars discussed a phenomenon called khusyu' which describes the state of an individual that is humbly submissive to Allah, in that the individual feels no difficulty in completing an instead difficult tasks such as prayer and being patient. This phenomenon is the exact phenomenon described by Mihalyi Csikzenmihaly as the state of "flow". In his flow dimension theory, Csikzenmihaly described the state of high focus and losing sense over unrelated things to the task at hand. The word "flow" is used as a metaphor to this state, as the high focus state of the subjects resembles the continuous, unobstructed flow of water. He argued that the state of flow is the phenomenon that occurs to an individual that is carrying tasks that are intrinsically motivating to the individual [27].

Gamification theoretical framework in short is the understanding of how humans are intrinsically motivated in doing things and the phenomena of an individual carrying out intrinsically motivating tasks. Selfdetermination theory and drive motivational theory listed autonomy, mastery, relatedness, and purpose as the recipe for intrinsic motivation. No formal paper was found about how Islamic philosophy relate to these motivational elements, but sources from Quran, Hadith, and discussions of Ibnu Khaldun support these elements. The motivational drives provide designers guidelines to design products or services that is intrinsically rewarding so that users may experience the flow state when using these products or services in their work. This is important as workers working in the state of flow has been shown to be more productive.

\subsection{Formal gamification framework}

Formal gamification framework is important in designing products and services based on gamification. Research has shown that gamification without formal framework are frequently found not meeting the intended target of the product or services. In addition, these product or services are also found to lose their long-term effectiveness or is not able to produce retention. Examples of formal gamification framework are MDA framework, Hexad framework, Sustainable Gamification Impact Framework, and Octalysis framework.

MDA (Mechanics, Dynamics, and Aesthetics) framework is the most basic gamification framework. In this framework, the design of a gamification system revolves around achieving Aesthetics through user Dynamics supported by the Mechanics of the gamification system. Mechanics are any user interface designed to enable the user to communicate with the system. The interaction between the user and the system is called Dynamics. Aesthetics are the user experience intended for the gamification system [5]. If we discuss Ibnu Khaldun's ideal educational system using MDA framework, in each level of the ideal education, Ibnu Khaldun specified the intended outcome of the levels first, for example, the goal of the first level is to introduce to the student about the body of knowledge, its boundaries and its uses. This is achieved by a process of explanation by teachers to the students which makes listening to the explanation as the Dynamics and the teachers as the Mechanics of this ideal educational system.

"Allah does not burden a person beyond that it can bear" (Al-Baqarah, verse 286)

This verse shows that not all person is created with equal potential or competencies and are tested according to their potential and competencies. Ibnu Khaldun and al-Ghazali realizes this in their discussion about education. They suggest that educators to avoid generalizing their students and instead understand different potential of their students and teach accordingly [16]. In gamification formal theories, human personality is also taken into consideration when designing gamification systems. Hexad framework specifies players or users into 6 different categories according their personalities or motivational inclinations. These categories are Achievers who are motivated by achievements, Free-spirited who values autonomy, Philanthropist who value altruism, Socializers who seeks for relatedness with other players or users, Players who value rules of the game or a system and Disruptors who find pleasure in finding loopholes of a system [28]. A good gamification system should be able to cater to all these personalities or depending on the customer, the system can be customized to maximize intrinsic user experience to the system.

Sustainable Gamification Impact framework is a tool used to test gamification systems to gauge its sustainability. Deriving the framework from motivational theories, Sustainable Gamification Impact emphasizes the importance of purpose, mastery and relatedness integration towards gamification system design. This means that a gamification system must have a feedback system that enables user experience to be gauged in term of purpose, master, and relatedness [29].

Combining all these frameworks, Yukai-Chou created the Octalysis framework with the Core Drives theory as the centre of his framework. He suggests that a designer must first determine the intended goal of a designed system and its sustainability goal. For short-term sustainability gamification system, Yukai-Chou suggests black hat core drives which can cause the repulsiveness towards some form of a loss to motivate quick user uptake of the system but is harmful in long-term. White hat core drives on the other hand focuses on pleasure out from creative process, mastery, meaning and spiritual empowerment that is suitable for systems intended for long-term sustainability. 
However, white hat core drives are slow on the uptake and may need to be supported with core drives aimed to extrinsically motivate users such as PBL. As for the intended goal for the gamification system, Yukai-Chou divided the Core Drives into left brain core drives which focuses on logical process, analysis, and extrinsic motivation. Right brain core drives on the other hand focuses on creative process, self-identity building and social dynamics [30].

Formal gamification framework work in a customer focused orientation where customer's needs are identified as Aesthetics of the gamification system upon which the Dynamics and Mechanics are build upon. Gamification framework also considers various profile of customers and build guidelines for designers to customize their gamification system. These systems must also be tested for their sustainability potential based on motivational drive theories. The integration of all these elements ensure designed gamification systems to be able to meet the intended goal and intended sustainability goal. No formal research has been done on gamification through Islamic philosophical lenses. Some Quran verses, Hadith and Islamic scholar views coincide with arguments in gamification's body of knowledge, but more must be done to identify the boundaries in Islamic philosophy about gamification systems.

\section{DISCUSSION}

A Madani society is a society which its members are balance in thought, spirit, and material. A nation with Madani society has a high potential to achieve Prosperous Nation state. A member of a Madani society must be educated in with necessary tools to equip the individual to balance one's thought, spirit, and material. Self-leadership is seen as a potential tool capable of enabling an individual to balance thought, spirit, and material. Gamification on the other hand, is seen as a capable tool to design balanced systems for Madani society users.

Self-leadership has been popularized in Western philosophical world as the process of an individual to influence oneself by setting self-direction and maintain self-motivation to complete tasks. Self-leadership consists of a set of normative and cognitive strategies that helps an individual to focus their behaviour, apply constructive cognitive pattern and leverage on one's natural inclinations to increase productivity. These strategies share a lot of common ground with akhlak training by Imam al-Ghazali. The difference between Western and Islamic philosophical view of self-leadership is that Islamic philosophy also consider spiritual element as an important element of human motivation and must be balanced with thought and materialistic tendencies. Meanwhile, Western philosophies does not discuss much about balance and spirit but focuses on goal-oriented approach to minimize discrepancies between any set of standards be it right or wrong standards with individual's performance.

Gamification is another body of knowledge that lately has been popularized in Western world. Gamification is the application of game design elements into non-game product or service design to increase user's motivation, engagement, and retention. Gamification theoretical framework consists of understanding elements of human motivation, evolution of human motivation from apathy to intrinsic motivation and phenomenon of carrying out intrinsically motivating tasks. No formal Islamic body of knowledge is available to be compared to gamification but Quran verses, hadith and Ibnu Khaldun's discussions have agreed with gamification theories in most areas. The theoretical frameworks are used to establish formal gamification frameworks that designs products or services in customer-oriented approach. Customer needs are set as the aesthetics of a gamification system upon which the system's dynamics and supporting mechanics are built upon. Failure of applying formal gamification techniques has been found to cause the system not to meet the intended goal and not sustainable in long run.

\section{CONCLUSION}

In conclusion, comparing Western philosophy and Islamic philosophy on self-leadership and gamifications, draws out some common grounds that can potentially benefit Madani society. Western philosophy focuses on harnessing the maximum potential of thought and material inclinations while Islamic philosophy seek to balance thought and material with spirit. By combining these two lines of thought, a self-leadership model based on gamification suited for Madani society can be designed. However, the model must be verified through formal research to assess its validity and impact. In a nutshell, a research must be done to study gamification based self-leadership model for a Madani society in Malaysia with considerations of Malaysians norms and cultures.

\section{REFERENCES}

[1] D. H. Pink, A whole new mind: Why right-brainers will rule the future. Penguin. 2006.

[2] S. R. Jasni, S. Zailani and H. Zainal, Pendekatan gamifikasi dalam pembelajaran bahasa Arab. Journal of Fatwa Management and Research, 2018. 358-367.

[3] R. M. Ryan and E. L. Deci, Intrinsic and extrinsic motivations: Classic definitions and new directions. Contemporary educational psychology, 25(1) (2000) 54-67.

[4] C. P. Neck and J. D. Houghton, Two decades of self-leadership theory and research. Journal of managerial psychology. 2006.

[5] B. Kim, Understanding gamification. ALA TechSource. 2015. 
[6] H. Salamun and A. Ab. Rahman, Pertimbangan Ketuhanan dalam Kepimpinan Politik Rabbani Masyarakat Melayu. International Conference on Empowering Islamic Civilization in the 21st Century. Terengganu: Universiti Sultan Zainal Abidin. 2015 647661.

[7] P. T. Razak, Nurturing a Balanced Person. Nilai: USIM Press. 2017.

[8] A. M. Jubran, Educational leadership: A new trend that society needs. Procedia-Social and Behavioral Sciences, 210 (2015) 28-34.

[9] K. Blanchard, Leading at a Higher Level, p 4 Prentice Hall. Ne. 2007.

[10] N. Fatwa, Corakkan kain putih. Retrieved from IKIM: Inspirasi Inforia Islami 2018. https://ikimfm.my/corakkan-kain-putih/

[11] A. Bandura, Social learning theory. General Learning Corporation. Library of. 1971.

[12] I. Kirsch, S. J. Lynn, M. Vigorito and R. R. Miller, The role of cognition in classical and operant conditioning. Journal of clinical psychology, 60(4) (2004) 369-392.

[13] K. Katni, Hakikat Manusia Mengikut Pemikiran alGhazali. International Seminar of Islamic Education. 2018.

[14] R. Wood, \& A. Bandura, Social Cognitive Theory of Organizational Management. Academy of Management Review. 1989.

[15] A. H. al-Ghazali, Bab 32. In A. H. al-Ghazali, Ihya' Ulumuddin (pp. 1203-1228). Damsyik: Illusion Network. 2010.

[16] A. H. al-Ghazali, Bab 20. In A. H. al-Ghazali, Ihya' Ulumuddin (Mutiara Penterjemahan) (pp. 599729). Damsyik: Illusion Network. 2010.

[17] J. D. Politis, Self-leadership behavioural-focused strategies and team performance. Leadership \& Organization Development Journal. 2006.

[18] A. H. al-Ghazali, Bab 27 (Taubat). In A. H. alGhazali, Ihya' 'Ulumuddin (Mutiara Penterjemahan) (pp. 1035-1084). Shah Alam: Illusion Network. 2010.

[19] I. M. an-Nawawi, Hadith 40. Kuala Lumpur: Dewan Pustaka Fajar. 1992.

[20] F. A. Ay, A. Karakaya and K. Yilmaz, Relations between self-leadership and critical thinking skills. Procedia-social and Behavioral sciences, 207 (2015) 29-41.
[21] C. P. Neck and C. C. Manz, Thought selfleadership: The influence of self-talk and mental imagery on performance. Journal of organizational behavior, 13(7) (1992) 681-699.

[22] A. H. al-Ghazali, Bab 1. In A. H. al-Ghazali, Ihya' Ulumuddin (Mutiara Penterjemahan) (pp. 1-14). Damsyik: Illusion Network. 2010.

[23] K. Kapp, Gamification: Separating fact from fiction. Chief Learning Officer, 13(3) (2014)

[24] R. M. Ryan and E. L. Deci, Self-determination theory and the facilitation of intrinsic motivation, social development, and well-being. American psychologist, 55(1) (2000) 68.

[25] D. H. Pink, Drive: The surprising truth about what motivates us. Penguin. 2011.

[26] A. B. Ibnu Khaldun, Bab 2, Fasal 17. In A. M. Ibnu Khaldun, M. Irham, M. Supar, \& A. Zuhri, Mukaddiman Ibnu Khaldun (Terjemahan Indonesia) (pp. 218-220). Jakarta: Pustaka Al-Kautsar. 2011.

[27] J. Nakamura and M. Csikszentmihalyi, The concept of flow. In Flow and the foundations of positive psychology. Springer, Dordrecht. 2014. 239-263

[28] A. Marczewski, User types. Even Ninja Monkeys Like to Play: Gamification, Game Thinking and Motivational Design, 1 (2015) 65-80.

[29] A. AlMarshedi, V. Wanick Vieira and A. Ranchhod, SGI: a framework for increasing the sustainability of gamification impact. International Journal for Infonomics, 8(1/2) (2015) 1044-1052.

[30] Y. K. Chou, Actionable gamification: Beyond points. Badges, and Leaderboards. 2015. 